University of Nebraska - Lincoln

DigitalCommons@University of Nebraska - Lincoln

\title{
Tillage Depth Effects on Soil Physical Properties, Sugarbeet Yield, and Sugarbeet Quality
}

J. D. Jabro

United States Department of Agriculture-Agricultural Research Service, jay.jabro@ars.usda.gov

W. B. Stevens

United States Department of Agriculture-Agricultural Research Service

W. M. Iversen

United States Department of Agriculture-Agricultural Research Service

R. G. Evans

United States Department of Agriculture-Agricultural Research Service

Follow this and additional works at: https://digitalcommons.unl.edu/usdaarsfacpub

Part of the Agricultural Science Commons

Jabro, J. D.; Stevens, W. B.; Iversen, W. M.; and Evans, R. G., "Tillage Depth Effects on Soil Physical Properties, Sugarbeet Yield, and Sugarbeet Quality" (2010). Publications from USDA-ARS / UNL Faculty. 540.

https://digitalcommons.unl.edu/usdaarsfacpub/540

This Article is brought to you for free and open access by the U.S. Department of Agriculture: Agricultural Research Service, Lincoln, Nebraska at DigitalCommons@University of Nebraska - Lincoln. It has been accepted for inclusion in Publications from USDA-ARS / UNL Faculty by an authorized administrator of DigitalCommons@University of Nebraska - Lincoln. 


\title{
Tillage Depth Effects on Soil Physical Properties, Sugarbeet Yield, and Sugarbeet Quality
}

\author{
J. D. JABRO, W. B. STEVENS, W. M. IVERSEN, \\ AND R. G. EVANS
}

Northern Plains Agricultural Research Laboratory, U.S. Department of Agriculture-Agricultural Research Service, Sidney, Montana, USA

\begin{abstract}
Tillage depth influences the soil-water-plant ecosystem, thereby affecting crop yield and quality. The effects of tillage depth on soil physical properties and sugarbeet (Beta vulgaris L.) yield and quality were evaluated. A field study composed of two tillage depths [10 cm, referred to as shallow (ST), and $20 \mathrm{~cm}$, referred to as deep (DT)] was conducted on a Lihen sandy loam soil in spring 2007 at the Agricultural Research Service (ARS) irrigated research farm near Williston, North Dakota. Soil bulk density $\left(\rho_{b}\right)$, gravimetric water content $\left(\theta_{w}\right)$, and saturated hydraulic conductivity $(K s)$ were measured three times during the growing season at four depth increments to $40 \mathrm{~cm}$ deep. Samples were taken approximately $0.5 \mathrm{~m}$ apart within the crop row of irrigated sugarbeet. Soil air-filled pore volume $\left(\varepsilon_{a}\right)$ was calculated from soil bulk density and water content data. Soil penetration resistance $(P R)$ was also measured in 2.5-cm increments to a depth of $35 \mathrm{~cm}$. Roots were hand-harvested from each plot, and each sample consisted of the roots within an area consisting of two adjacent rows $1.5 \mathrm{~m}$ long. Soil $\rho_{b}$ was greater in $S T$ than in DT, whereas Ks was greater with DT than with ST. Soil PR was significantly greater in ST than in DT at the 0- to 20-cm depth. Soil $\theta_{w}$ and $\varepsilon_{a}$ were slightly greater in DT than those under ST. Although tillage depth had no significant effect on sugarbeet population, root yield, or sucrose content, a small difference in sucrose yield between two depths of tillage may be attributed to reduced $\rho_{b}$, increased water intake, improved aeration, and increased response to nitrogen uptake under DT than under ST. It was concluded that tillage depth enhanced soil physical quality and had little effect on sugarbeet yield or quality.
\end{abstract}

Keywords Aeration, bulk density, hydraulic conductivity, penetration resistance, root nitrate, root sucrose, sugarbeet, water content

\section{Introduction}

Tillage depth and intensity alter the soil physical and chemical properties that affect plant growth and crop yields (Strudley, Green, and Ascough 2008). Soil loosening by means of deep-tillage systems improves water infiltration, internal drainage, and aeration in the soil;

This article not subject to U.S. copyright law.

Received 20 September 2008; accepted 23 March 2009.

Mention of trade names, proprietary products, or specific equipment is intended for reader information only and does not constitute a guarantee or warranty by the USDA-ARS, nor does it imply approval of the product named to the exclusion of other products.

Address correspondence to J. D. Jabro, Northern Plains Agricultural Research Laboratory, USDA-ARS, 1500 N. Central Avenue, Sidney, MT 59270. E-mail: jay.jabro@ ars.usda.gov 
increases root depth, intensity, and development; and allows for deeper fertilizer placement (Mathers et al. 1971; Bennie and Botha 1986; Diaz-Zorita 2000; Strudley, Green, and Ascough 2008).

Soil bulk density, penetration resistance (PR), and water movement in the soil, all indices of soil compactness and porosity, depend on depth and method of tillage (Hamza and Anderson 2002, 2003, 2005). Therefore, assessing the effect of tillage depth and method on these soil physical properties may explain variability in crop growth, crop development, yield, and quality (Hamza and Anderson 2002, 2003, 2005). Generally speaking, all tillage methods reduced soil bulk density and penetration resistance to the depth of tillage (Erbach et al. 1992). In other studies, water infiltration was greater in tilled soil than in untilled soil (Erbach et al. 1992; Ferreras et al. 2000). In a recent study, Alamouti and Navabzadeh (2007) reported that deep tillage had the greatest effect on soil bulk density, organic carbon, infiltration rate, and crop yield compared to semideep and shallow tillage systems. They also concluded that soil bulk density, infiltration rate, and crop yield increased with increasing the plowing depth.

Many deep-tillage studies have been conducted, and only a few of them have been reported because of lack or inconsistency of yield responses to deep tillage (Popp et al. 2001). Early studies presented conflicting results in terms of deep-tillage influences on crop yield. Kohnke and Bertrand (1956) and Mathers et al. (1971) concluded that deep tillage and fertilizers have increased crop yields, whereas Beaver and Farnsworth (1940) and Mathers et al. (1971) reported that increased sugarbeet yield on deep-tilled soils was related to improvement in soil aeration and water retention. Other studies showed that deep tillage alone did not increase crop yield (Woodruff and Smith 1947; Jamison and Thornton 1960). Moreover, Richard, Boiffin, and Duval (1995) reported that a reduction in sugarbeet yield under shallow and direct-drilling tillage was related to low plant density. Kouwenhoven et al. (2002) found that sugarbeet yield was reduced up to $9 \%$ by reducing tillage depth to $12-18 \mathrm{~cm}$ compared with moldboard plowing at a depth of $20-30 \mathrm{~cm}$.

Nevertheless, the effects of deep-soil plowing on soil physical properties as well as crop yield and quality are not well documented. This study consequently sought to evaluate the effects of tillage depth on soil PR, bulk density $\left(\rho_{\mathrm{b}}\right)$, saturated hydraulic conductivity $(\mathrm{Ks})$, gravimetric water content $\left(\theta_{\mathrm{w}}\right)$, air-filled pore volume $\left(\varepsilon_{\mathrm{a}}\right)$, and sugarbeet (Beta vulgaris L.) yield and quality in a sandy loam soil.

\section{Materials and Methods}

\section{Site Description and Soil}

This study was conducted in spring 2007 at the U.S. Department of AgricultureAgricultural Research Service (USDA-ARS) Nesson Valley irrigated research farm, located approximately $37 \mathrm{~km}$ east of Williston, North Dakota $\left(48.1640^{\circ} \mathrm{N}, 103.0986^{\circ} \mathrm{W}\right)$.

The soil at the site is classified as a Lihen sandy loam (sandy, mixed, frigid Entic Haplustoll), consisting of very deep, well, or somewhat excessively drained soil. Particlesize-distribution analysis indicated the textural class of the surface horizon $(0$ to $30 \mathrm{~cm})$ to be consistently within the sandy loam classification. The amount of sand, silt, and clay in the soil at 0 - to 30 -cm depth ranged from 640 to 674,176 to 184 , and 150 to $166 \mathrm{~g} \mathrm{~kg}^{-1}$, respectively.

The experimental design was a randomized complete block with six replicates. Plot size was variable because of the width of the equipment and limited field space 
( 6 to $8 \mathrm{~m}$ wide $\times 30 \mathrm{~m}$ long). Irrigation water was applied using an overhead linear sprinkler irrigation system.

\section{Soil Characteristic Measurements}

Intact cylindrical soil cores $(5 \mathrm{~cm}$ long $\times 5 \mathrm{~cm}$ in diameter) were collected on 16 June, 11 July, and 12 September 2007 at four depths for each plot under each tillage depth. Bulk density and $\theta_{\mathrm{w}}$ were evaluated using oven-dried undisturbed soil cores to determine mass of oven-dried soil per volume of core. Final infiltration rate for the soil surface $(0-10 \mathrm{~cm})$ and saturated hydraulic conductivity (Ks) for subsurface layers (below $10 \mathrm{~cm}$ ) were measured on 16-24 June, 11-15 July, and 12-13 September for each plot under each tillage depth using pressure head infiltrometer and constant head well permeameter, respectively (Reynolds and Elrick 2002). All measurements were made at depth increments of 0-10, 10-20, 20-30, and 30-40 cm, approximately $0.5 \mathrm{~m}$ apart within the crop row of irrigated sugarbeet. Each soil measurement was replicated six times.

Soil PR as a cone index was measured on 6 June 2005 by pushing a hand-held digital cone-tipped (12.8-mm diameter) penetrometer (Field Scout, SC 900 Soil Compaction Meter; Spectrum Technologies, Inc., Plainfield, Ill.) at three locations within a $30-\mathrm{cm}$ radius at each plot where soil cores for $\rho_{\mathrm{b}}$ were extracted. Soil PR readings were recorded in $2.5-\mathrm{cm}$ increments to $35 \mathrm{~cm}$ deep. Soil PR measurements were not made on 11 July or 12 September 2007 because of the sensitivity of the penetrometer's sensor to vegetative parts of sugarbeets.

The air-filled pore volume $\left(\varepsilon_{\mathrm{a}}\right)$ for each soil depth increment was calculated from total soil porosity $(\varepsilon)$ as

$$
\varepsilon=\left(1-\rho_{\mathrm{b}} / 2.65\right)
$$

where $2.65 \mathrm{Mg} \mathrm{m}^{-3}$ is the soil particle density. Volumetric water content $\left(\theta_{\mathrm{v}}\right)$ was estimated as

$$
\theta_{\mathrm{v}}=\theta_{\mathrm{w}} \times \rho_{\mathrm{b}} / \rho_{\mathrm{w}}
$$

where $\rho_{\mathrm{w}}$ is a constant of $1 \mathrm{Mg} \mathrm{m}^{-3}$ of density of water. The $\varepsilon_{\mathrm{a}}$ is calculated as

$$
\varepsilon_{\mathrm{a}}=\varepsilon-\theta_{\mathrm{v}}
$$

\section{Tillage Treatments and Field Management Practices}

The shallow-tillage (ST) treatment consisted of a pass with a tandem disk (model 370, International Harvester Company, Chicago, Ill.) at $10 \mathrm{~cm}$ deep. The spacing between the 48-cm-diameter discs was $20 \mathrm{~cm}$. The deep tillage treatment was performed with a chisel plow (model 200, John Deere, Moline, Ill.) with 5-cm straight spikes set to approximately $20 \mathrm{~cm}$ deep. The shank spacing on the chisel plow was $30 \mathrm{~cm}$.

All of the plots received a finishing pass with a cultipacker (model 415, International Harvester Company, Chicago, Ill.) at a $45^{\circ}$ angle to the planting direction.

Dry fertilizer was applied with a Valmar (model 12555PT, Valmar Airflo Inc., Elie, Manitoba, Canada) air-assisted spreader. The amounts of nitrogen $(\mathrm{N})$, phosphorus $(\mathrm{P})$, potassium (K) fertilizer applied were respectively 76, 50, and $94 \mathrm{~kg} \mathrm{ha}^{-1}$. 
Sugarbeet (variety American Crystal 927, Moorehead, Minn.) was planted on 24 April 2007 with within-row spacing of $13 \mathrm{~cm}\left(12.6\right.$ seeds $\left.\mathrm{m}^{-2}\right)$ and a row spacing of $61 \mathrm{~cm}$. The planter used was a six-row John Deere MaxEmerge (model 1700, Moline, Ill.). The crop was cultivated on 4 June 2007 with a single-sweep row crop cultivator (H \& S model 6R-24SB/0S, H \& S, Stephen, Minn.).Weeds were controlled with herbicides.

\section{Sugarbeet Sampling and Processing}

Two root samples were hand-harvested on 26 September 2007 from each plot. Each sample consisted of roots from a total of $3 \mathrm{~m}$ of row, with $1.5 \mathrm{~m}$ from one row and 1.5 from an adjacent row. The 1.5-m row segments were not side by side, but sequential, so one began where the other ended (Figure 1). The average of the two samples was used to represent yield and quality parameters for that plot in the analysis.

The roots were hand-topped to the lowest leaf scar. All beets less than $5.715 \mathrm{~cm}$ in diameter were discarded, as these would be too small to be harvested by a commercial harvester. The number of these unharvestable beets was recorded. The samples were analyzed by Sidney Sugars (Sidney, Montana, USA) in the same laboratory used for the analysis of samples taken from grower's trucks during harvest. The number of roots, gross weight, weight before crowning, weight after crowning, percent sucrose, and $\mathrm{NO}_{3}-\mathrm{N}$ were analyzed by the laboratory. Extracted juice was also sent to Agterra Technologies Inc. (Sheridan, Wyo.) for impurity analysis. Laboratory results for sodium (Na), K, amino N, impurity index, and sucrose loss to molasses (SLM) were obtained from this laboratory as well. Sucrose yield was calculated by multiplying the fresh-weight root yield $\left(\mathrm{Mg} \mathrm{ha}^{-1}\right)$ by the fresh-weight root sucrose concentration $\left(\mathrm{g} \mathrm{kg}^{-1}\right)$ adjusted for SLM.

\section{Statistical Methods}

Statistical analyses were accomplished using the analysis of variance of mixed models procedure by SAS software (SAS Institute 2003). The statistical analysis was used to test

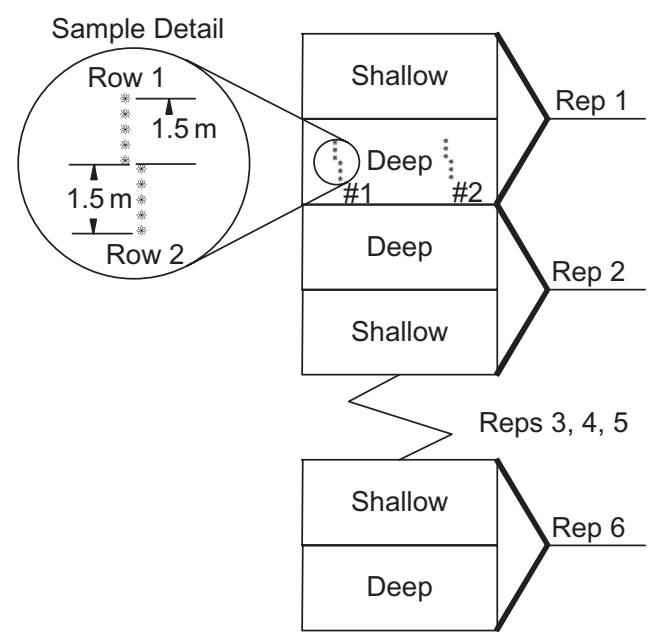

Figure 1. Layout of experimental field plots and sampling scheme for sugarbeet yield. 
the differences between treatments for crop yield, quality parameters, and soil variables. Data were analyzed using a randomized complete block design.

\section{Results and Discussion}

Tillage treatments significantly affected PR, $\rho_{\mathrm{b}}$, and Ks but not $\theta_{\mathrm{w}}$ and $\varepsilon_{\mathrm{a}}$ (Table 1 ). Tillage treatment did not have a significant effect on sugarbeet yield and quality (Table 2). The interaction effects of tillage method and soil depth as well as tillage method and time of sampling were not significant at the 0.05 probability level.

\section{Soil Penetration Resistance (PR)}

The effect of tillage depth on soil PR was significant at the 0.05 probability level (Figure 2). Figure 2 presents the PR profiles under both tillage treatments to a $35-\mathrm{cm}$ soil depth. The PR under ST was significantly greater than that under deep tillage (DT) from 0 to $20 \mathrm{~cm}$ deep, whereas below that depth $(<20 \mathrm{~cm})$ the PR was not affected by the depth of tillage.

\section{Table 1}

Means of soil physical properties as affected by tillage depth in sandy loam soil at Nesson valley

\begin{tabular}{lcccc}
\hline Tillage depth $(\mathrm{cm})$ & $\rho_{\mathrm{b}}{ }^{a}\left(\mathrm{Mg} \mathrm{m}^{-3}\right)$ & $\theta_{\mathrm{w}}{ }^{a}\left(\mathrm{~g} \mathrm{~g}^{-1}\right)$ & $\varepsilon_{\mathrm{a}}{ }^{a}\left(\mathrm{~m}^{3} \mathrm{~m}^{-3}\right)$ & $\mathrm{Ks}^{a}\left(\mathrm{~mm} \mathrm{~h}^{-1}\right)$ \\
\hline 0 to 10 (shallow) & 1.57 & 0.133 & 0.197 & 30.4 \\
0 to 20 (deep) & 1.54 & 0.135 & 0.210 & 41.5 \\
& 0.028 & Analysis of & variance, $\mathrm{P}>\mathrm{F}$ & 0.028 \\
\hline
\end{tabular}

${ }^{a} \rho_{\mathrm{b}}$ is soil bulk density, $\theta_{\mathrm{W}}$ is gravimetric water content, $\varepsilon_{\mathrm{a}}$ is air-filled pore volume, and Ks is saturated hydraulic conductivity of soil.

Notes. The values are averaged across four soil depths and three sampling dates. The p-value compares means of two tillage depths using the analysis of variance.

\section{Table 2}

Components of sugarbeet yield as affected by depth of tillage in sandy loam soil at Nesson valley

\begin{tabular}{|c|c|c|c|c|c|c|}
\hline $\begin{array}{l}\text { Tillage } \\
\text { depth }(\mathrm{cm})\end{array}$ & $\begin{array}{c}\text { Root } \\
\text { yield } \\
\left(\mathrm{Mg} \mathrm{ha}^{-1}\right)\end{array}$ & $\begin{array}{l}\text { Root sucrose } \\
\text { concentration } \\
\quad\left(\mathrm{g} \mathrm{kg}^{-1}\right)\end{array}$ & $\begin{array}{c}\text { Sucrose } \\
\text { yield }^{a} \\
\left(\mathrm{Mg} \mathrm{ha}^{-1}\right)\end{array}$ & $\begin{array}{c}\mathrm{SLM}^{b} \\
\left(\mathrm{~g} \mathrm{~kg}^{-1}\right)\end{array}$ & $\begin{array}{l}\text { Root nitrate } \\
\left(\mathrm{Mg} \mathrm{kg}^{-1}\right)\end{array}$ & $\begin{array}{l}\text { Population } \\
\text { (plants } \\
\mathrm{ha}^{-1} \text { ) }\end{array}$ \\
\hline $\begin{array}{l}0 \text { to } 10 \\
\text { (shallow) }\end{array}$ & 60.1 & 180.6 & 10.85 & 8.41 & 19.28 & 96237 \\
\hline \multirow{3}{*}{$\begin{array}{l}0 \text { to } 20 \\
\quad(\text { deep })\end{array}$} & 65.5 & 182.2 & 11.38 & 8.07 & 22.02 & 101318 \\
\hline & \multicolumn{6}{|c|}{ Analysis of variance, $\mathrm{P}>\mathrm{F}$} \\
\hline & 0.150 & 0.356 & 0.063 & 0.298 & 0.496 & 0.233 \\
\hline
\end{tabular}

${ }^{a}$ Sucrose yield $=$ root yield $\times$ sucrose concentration.

${ }^{b}$ SLM is sugar loss to molasses.

Note. The p-value compares two means of tillage depths using the analysis of variance. 


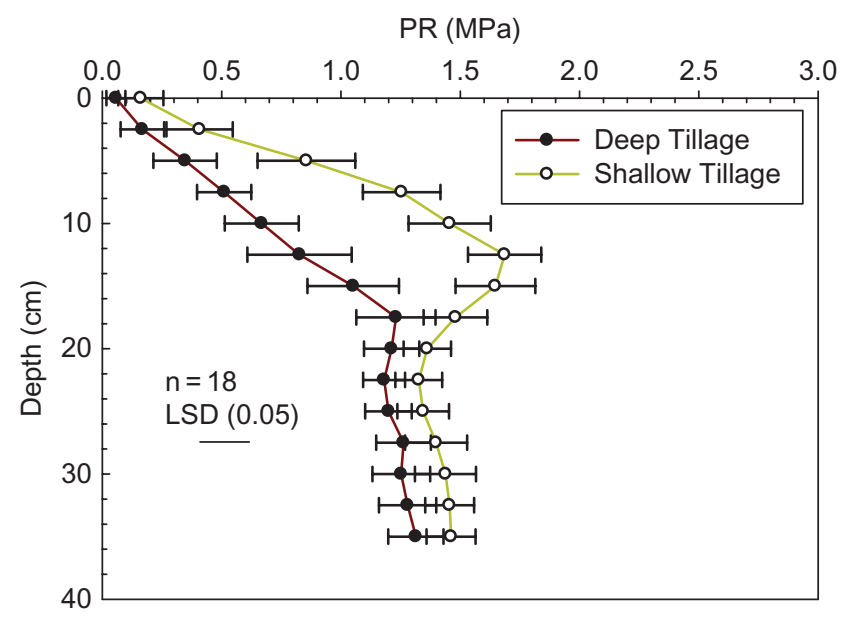

Figure 2. Effect of tillage depth on soil penetration resistance (PR) at 0 to $35 \mathrm{~cm}$ deep. LSD is least squares difference, significant at $P=0.05$. Each point is an average of 18 measurements. Horizontal error bars are two standard errors around the mean.

Lower PR with DT in the 0- to 20-cm depth was mainly a result of soil loosening and manipulation by deeper plowing, which thereby caused more macropores to form than the ST treatment (Figure 2). Soil PR in DT and ST plots averaged 0.912 and 1.203 MPa, respectively across the 0 - to $35-\mathrm{cm}$ depth range, whereas the mean PR values in the 0 - to 20-cm depth were 0.783 and $1.127 \mathrm{MPa}$ for DT and ST, respectively. The lower PR with DT was likely the result of tillage-induced soil loosening caused by deeper penetration of tillage implement. Similar trends in PR with respect to tillage depth on PR were reported by Erbach et al. (1992) and Etana et al. (1999).

\section{Soil Bulk Density $\left(\rho_{b}\right)$}

Over the course of the study, tillage treatments significantly affected soil $\rho_{\mathrm{b}}$. Soil $\rho_{\mathrm{b}}$ decreased with increasing the depth of tillage (Table 1). Mean $\rho_{\mathrm{b}}$ values were 1.57 and 1.54 $\mathrm{Mg} \mathrm{m}^{-3}$ for ST and DT, respectively. Regular DT usually loosens and inverts soil more than ST, thereby forming more macropores under this tillage than under ST systems. These findings correspond directly with soil compaction results presented in Figure 2, where soil compaction was less in DT than in ST plots because of greater soil loosening and manipulation under the DT system. Overall, these findings widely agreed with results found by Hakansson, Voorhees, and Riley (1988); Lower and Schuler (1991); Erbach et al. (1992); and Alamouti and Navabzadeh (2007), who found greater soil $\rho_{\mathrm{b}}$ values in shallow-depth tillage systems.

\section{Soil Saturated Hydraulic Conductivity, Ks}

Soil Ks was significantly affected by the depth of tillage and was greater in DT than in ST (Table 1). Mean soil Ks values were 41.5 and $30.4 \mathrm{~mm} \mathrm{~h}^{-1}$ for DT and ST, respectively. The increase in Ks with DT is related to soil loosening, greater porosity, and better pore continuity in DT plots than in ST plots. The Ks findings associate directly with the PR results presented in Figure 2, where soil compaction was less in DT than in ST plots. 
These results agreed with those of Rao, Hay, and Bateman (1960) and Mannering, Meyer, and Johnson (1966) but differed from those of Glenn and Dotzenko (1966).

\section{Gravimetric Water Content, $\theta_{w}$ and Air-Filled Pore Volume, $\varepsilon_{a}$}

The $\theta_{\mathrm{W}}$ was not influenced by the depth of tillage (Table 1 ). Averages of $\theta_{\mathrm{w}}$ across the 0 - to $40-\mathrm{cm}$ depth and three dates were 0.133 and $0.135 \mathrm{~g} \mathrm{~g}^{-1}$ in ST and DT, respectively. Although no significant differences were found between ST and DT, the ST plots tended to be slightly drier than DT plots.

Soil $\varepsilon_{\mathrm{a}}$ increased with increasing the depth of tillage (Table 1). The $\varepsilon_{\mathrm{a}}$ was significantly greater in DT than in the ST at the 0.1 probability level. Soil $\varepsilon_{\mathrm{a}}$ values were 0.210 and 0.197 $\mathrm{m}^{3} \mathrm{~m}^{-3}$ for DT and ST, respectively. This difference between the two tillage depths under consideration is associated with the greater soil macroposity produced by DT as a result of greater soil loosening under this tillage than in the ST tillage system. This trend in $\varepsilon_{\mathrm{a}}$ indicated better soil aeration to plow depth in DT plots than in ST plots. The DT promoted the formation of large air-filled pores, increasing soil aeration to plow depth.

\section{Sugarbeet Yield and Quality}

Sugarbeet yield and quality components were not significantly affected by the depth of tillage (Table 2); however, sucrose yield was significantly greater in DT than in ST at the 0.1 probability level, an increase of $4 \%$ (Table 2). Root yield, root sucrose, root nitrate, and plant population tended to be slightly greater under DT than under ST plots (Table 2). Sugarbeet quality was not significantly affected by tillage, with variation in nitrate content and SLM being very small and offsetting (Table 2).

The small difference in sucrose yield between DT and ST treatments may have been related to variations in soil $\rho_{\mathrm{b}}, \mathrm{PR}$, porosity, aeration, and water and nitrate intake and movement through the soil profile. Deep plowing improves soil conditions more than shallow plowing because it loosens the soil, improving water intake rate and aeration, increasing root depth and development, and allowing for deeper fertilizer movement in the soil profile. Moreover, the small reduction in sucrose yield in the ST treatment (Table 2) could also be associated with a plant density less under the ST treatment than under the DT treatment (Richard, Boiffin, and Duval 1995).

\section{Conclusions}

This study evaluated the effects of tillage depth on soil physical properties and on sugarbeet yield and quality. Soil $\rho_{\mathrm{b}}$ and Ks were significantly affected by the depth of tillage. Soil $\rho_{\mathrm{b}}$ was greater in ST than in DT, whereas Ks was greater with DT than with ST. Soil PR was significantly greater in ST than in DT at the 0 - to $20-\mathrm{cm}$ depth. Soil $\theta_{\mathrm{w}}$ was not affected by tillage, and $\varepsilon_{\mathrm{a}}$ was slightly greater in DT than those under ST. Deep tillage promoted the formation of air-filled pores more than ST, possibly increasing soil aeration to the plow depth. Although tillage depth had no significant effect on sugarbeet population, root yield, or sucrose content, a $4 \%$ difference in sucrose yield between two depths of tillage may be attributed to reduced $\rho_{\mathrm{b}}$, increased water intake, improved aeration, and increased response to $\mathrm{N}$ uptake under DT than under ST. It was concluded that tillage depth enhanced soil physical qualities and had no effect on most sugarbeet yield and quality parameters, with only a slight effect on sucrose yield detectable at the $0.1 \%$ probability level. More in-depth 
work is required to address whether DT (traditional) is viable and cost-effective compared with ST practices.

\section{Acknowledgments}

The authors extend their sincere thanks to Mr. Dale Spracklin for his assistance in soil sampling and measuring soil physical properties. The authors also thank Mrs. Genevieve Gwynne for her editorial remarks. The helpful suggestions and comments of two internal reviewers, Dr. M. Abou Najm at Purdue University and R. Lartey at the Northern Plain Agricultural Research Laboratory (NPARL) in Sidney, three anonymous reviewers, and Dr. Gretchen Bryson, associate executive editor of the journal, are greatly appreciated. Their suggestions immensely improved the readability and quality of the article.

\section{References}

Alamouti, M. Y., and M. Navabzadeh. 2007. Investigating of plowing depth effect on some soil physical properties. Pakistan Journal of Biological Sciences 10:4510-4514.

Bennie, A. T. P., and F. J. P. Botha. 1986. Effect of deep tillage and controlled traffic on root growth, water use efficiency, and yield of irrigated maize and wheat. Soil and Tillage Research 7:85-95.

Beaver, L. D., and R. R. Fransworth. 1940. Soil structure effects in the growth of sugar beets. Soil Science Society of America Journal 5:45-48.

Diaz-Zorita, M. 2000. Effect of deep tillage and nitrogen fertilization interactions on dryland corn (Zea mays L.) productivity. Soil and Tillage Research 54:11-19.

Erbach, D. C., J. G. Benjamin, R. M. Cruse, M. A. Elamin, S. Mukhtur, and C. H. Choi. 1992. Soil and corn response to tillage with paraplow. Transactions of the ASAE 35:1347-1354.

Etana, A., I. Hakansson, E. Zagal, and S. Bucas. 1999. Effects of tillage depth on organic content and physical properties in five Swedish soils. Soil and Tillage Research 52:129-139.

Ferreras, L. A., J. L. Costa, F. O. Garcia, and C. Pecorari. 2000. Effect of no-tillage on some physical properties of structural degraded Petrocalcic Paleudoll of southern Pampa of Argentina. Soil and Tillage Research 54:31-39.

Glenn, D. M., and A. D. Dotzenko. 1978. Minimum vs conventional tillage in commercial sugar beet production. Agronomy Journal 70: 341-344.

Hakansson, I., W. B. Voorhees, and H. Riley. 1988. Vehicle and wheel factors influencing soil compaction and crop response in different traffic regimes. Soil and Tillage Research 11:239-282.

Hamza, M. A., and W. K. Anderson. 2002. Improving soil physical fertility and crop yield on a clay soil in western Australia. Australian Journal of Agricultural Research 53 (5): 615-620.

Hamza, M. A., and W. K. Anderson. 2003. Responses of soil properties and grain yields to deep ripping and gypsum application in a compacted loamy sand soil contrasted with a sandy clay loam soil in western Australia. Australian Journal of Agricultural Research 54:273-282.

Hamza, M. A., and W. K. Anderson. 2005. Soil compaction in cropping systems: A review of the nature, causes, and possible solutions. Soil and Tillage Research 82 (2): 12-145.

Jamison, V. C., and J. F. Thornton. 1960. Results of deep fertilization and subsoiling on a claypan soil. Agronomy Journal 52:193-195.

Kohnke, H., and A. R. Bertrand. 1956. Fertilizing the subsoil for better water utilization. Soil Science Society of America Journal 20:581-586.

Kouwenhoven, J. K., U. D. Perdok, J. Boer, and G. J. M. Oomen. 2002. Soil management by shallow mouldboard ploughing in the Netherlands. Soil and Tillage Research 65:125-139.

Lowery, B., and R. T. Schuler. 1991. Temporal effects of subsoil compaction on soil strength and plant growth. Soil Science Society of America Journal 55:216-223.

Mannering, J. V., L. D. Meyer, and C. B. Johnson. 1966. Infiltration and erosion as affected by minimum tillage for corn. Soil Science Society of America Proceedings 30:101-105. 
Mathers, A. C., G. C. Wilson, A. D. Schnieder, and P. Scott. 1971. Sugarbeet response to deep tillage, nitrogen, and phosphorous on Pullman clay loam. Agronomy Journal 63:474-477.

Popp, M. J., T. C. Keisling, C. R. Dillon, and P. M. Manning. 2001. Economic and agronomic assessment of deep tillage in soybean production on Mississippi river valley soils. Agronomy Journal 93:164-169.

Rao, A. S., R. C. Hay, and H. P. Bateman. 1960. Effect of minimum tillage on physical properties of soils and crop response. Transactions of the ASAE 3:3-10.

Richard, G., J., Boiffin, J. and Y. Duval. 1995. Direct drilling of sugarbeet (Beta vulgaris L.) into a cover crop: Effects on soil physical conditions and crop establishment. Soil and Tillage Research 34:169-185.

Reynolds, W. D., and D. E. Elrick. 2002. Pressure infiltrometer. In Methods of soil analysis, part 4: Physical methods, ed. J. H. Dane and G. C. Topp, 826-836. Madison, Wisc.: Soil Science Society of America.

Strudley, M. W., T. R. Green, and J. C. Ascough II. 2008. Tillage effects on soil hydraulic properties in space and time. Soil and Tillage Research 99:4-48.

Woodruff, C. M., and D. D. Smith. 1947. Subsoil shattering and subsoil liming for crop production on clay pan soils. Soil Science Society of America Journal 11:519-542. 